\title{
Sugarcane Biomass \\ Production and Renewable Energy
}

Moses Isabirye, D.V.N Raju, M. Kitutu, V. Yemeline, J. Deckers and J. Poesen

Additional information is available at the end of the chapter

http://dx.doi.org/10.5772/56075

\section{Introduction}

Bio-fuel production is rooting in Uganda amidst problems of malnutrition and looming food insecurity "in [1,2]". The use of food for energy is a Worldwide concern as competition for resources between bio-fuel feedstocks and food crop production is inevitable. This is especially true for the category of primary feedstocks that double as food crops. Controversy surrounds the sustainability of bio-fuels as a source of energy in Uganda.

Given the above circumstances, adequate studies are required to determine the amount of feedstock or energy the agricultural sector can sustainably provide, the adequacy of land resources of Uganda to produce the quantity of biomass needed to meet demands for food, feed, and energy provision. Sugarcane is one of the major bio-fuel feed-stocks grown in Uganda.

Growth in sugarcane cultivation in Uganda is driven by the increased demand for sugar and related by-products. Annual sugar consumption in Uganda is estimated at $9 \mathrm{~kg}$ per capita with a predicted per capita annual consumption increase by $1 \%$ over the next 15 years "in [3]".

This growth has resulted in increased demand for land to produce staple foods for households and thus encroaching on fragile ecosystems like wetlands, forests and shallow stoney hills and, a threat to food security " in [4]". The situation is likely to worsen with the advent of technology advancements in the conversion of biomass into various forms of energy like electricity and biofuels. A development that has attracted government and investors into the development of policies "in $[5,6]$ " that will support the promotion of biofuels in Uganda "in [7]".

Competition for land resources and conflicts in land use is imminent with the advent of developments in the use of agricultural crop resources as feedstocks for renewable energy 
production. Sugarcane is one such crop for which production is linked to various issues including the sustainability of households in relation to food availability, income and environmental integrity. The plans for government to diversify on altnertive sources of energy with focus on biofuels and electricity generation has aggravated the situation. This chapter aims at demonstrating how sugarcane biomass can sustainably be produced to support fuel and electrical energy demands while conserving the environment and ensuring increased household income and food security.

This study was conducted with a major objective of assessing sustainable production of biofuels and electricity from sugarcane biomass in the frame of household poverty alleviation, food security and environmental integrity.

\section{Research methods}

The assessment of sugarcane production potential is done for the whole country. The rest of the studies were done at the Sugar estate and the outgrower farmers.

\subsection{Assessment of sugarcane production potential}

The overall suitability assessment involved the use of the partial suitability maps of temperature, rainfall and soil productivity ratings (Figures 1 and 2). An overlay of the three maps gave suitability ratings for sugarcane bio-fuel feedstock.
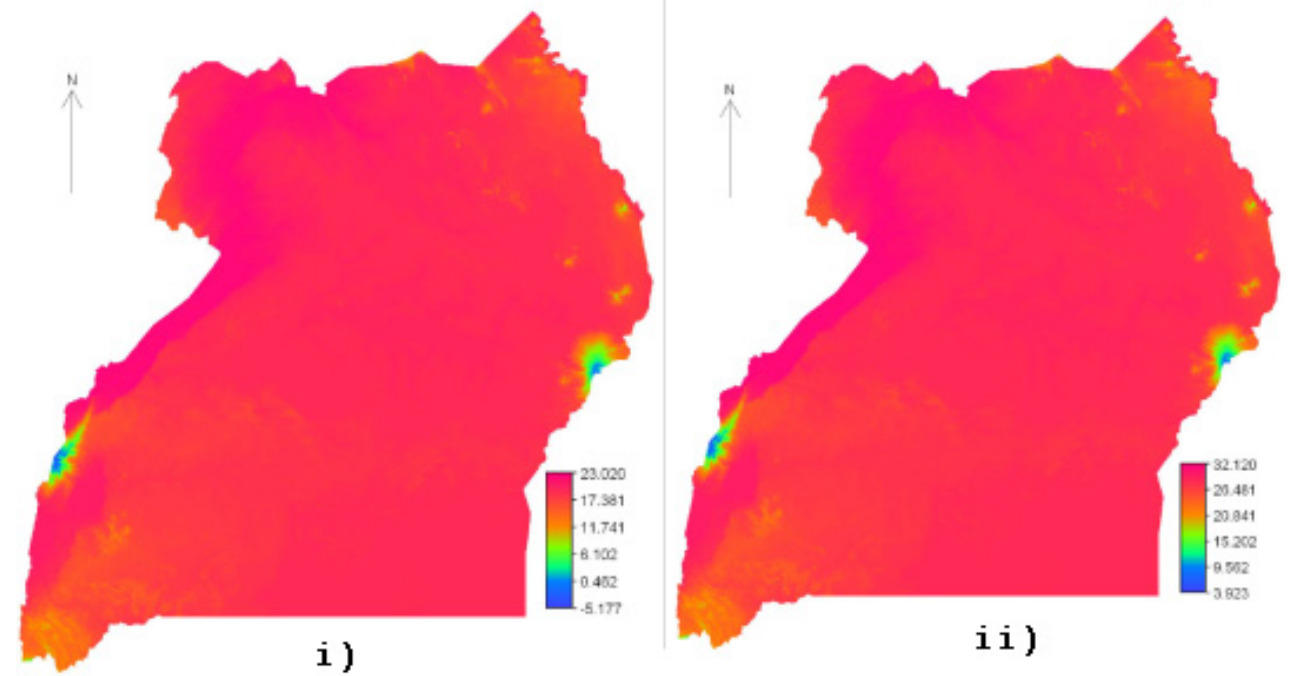

Figure 1. i) Minimum temperatures and maximum temperatures ii) "in [8] ".

Subtraction of gazetted areas, wetlands and water bodies produced final suitability maps and tables presented in the results. Steep areas have not been excluded since they are associated with highlands which are densely populated areas. It is hoped that soil 
conservation practices will be practiced where such areas are considered for production of sugarcane feedstock. Urban areas, though expanding, are negligible and have not been considered in the calculations.

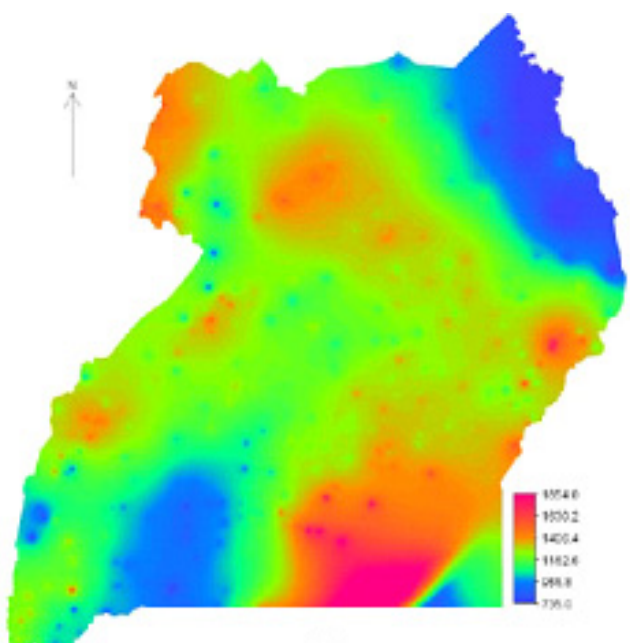

i)

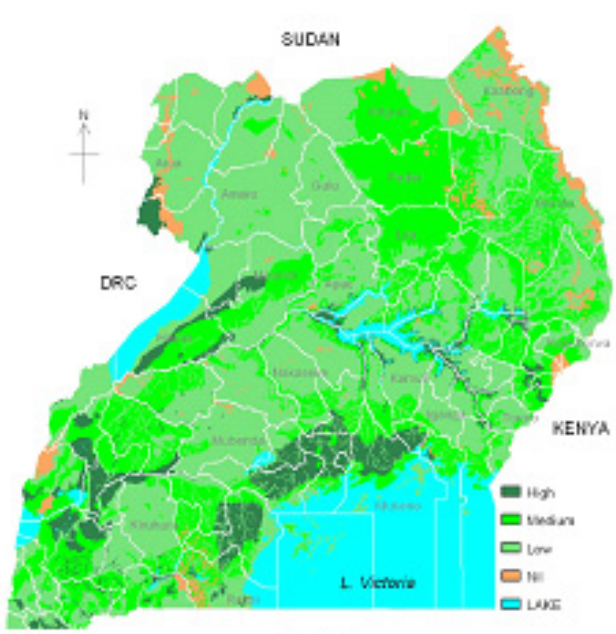

i i )

Figure 2. i) Mean annual rainfall " in [8]"; ii) Soil productivity ratings " in [9] ".

The suitability of the land resource quality for sugarcane was based on sets of values which indicate how well each cane requirement is satisfied by each land quality say: mean annual rainfall, minimum and maximum temperatures and soil productivity. The four suitability classes (rating), assessed in terms of reduced yields, and were defined according to " in [10] ". Potential land-use conflict visualization also gives an indication of land available for the production of sugarcane bio-fuel feedstocks. Conflict visualization for food versus sugarcane was done by an overlay of suitability maps of maize with sugarcane. Land-use conflict with gazetted areas was assessed by overlaying gazetted area maps with sugarcane suitability map.

\subsection{Sustaining sugarcane biomass productivity}

The total biomass production of five commercial sugarcane varieties grown on the estate across all crop cycles (plant and three ratoons) was developed.

The data on cane yield and cane productivity of plant and ratoon crops between 1995-1996 and 2009-2010 were collected from annual reports and compared to experimental data. The total bio-mass (cane, trash and tops) production in plant and two ratoons were recorded at harvest age i.e. 18 and 17 months for plant and ratoon crops respectively. Data was collected from three locations of plot size $54 \mathrm{~m}^{2}$ (4 rows of $10 \mathrm{~m}$ length). Nutrient status of crop residues on oven dry basis was adopted as suggested by " see [11] " for calculation of nutrient return to the soil and nutrients available to succeeding crop. 
A replicated trial with four replications was established during 2009-2010 with different levels of chemical fertilizers and factory by-products (filter mud and boiler ash) to test their influence on cane and sugar yields.

Semi-commercial trials were established on the estate to study the influence of green manuring with sunn hemp against no green manured blocks (control), aggressive tillage against reduced tillage, and intercropping with legumes on cane yield and juice quality parameters.

Field studies were conducted during 2002-2004 and 2007-2009 to evaluate the influence of different levels of Nitrogen (N), Phosphorus (P), Potassium (K) and sulphur (S) on cane yield and juice quality of plant crop of sugarcane.

The cane yield data on green cane vs burnt cane harvesting systems, and aggressive vs reduced tillage operations were collected and analysed for biomass yield.

\subsection{Assessment of potential biofuel productivity and cane biomass electricity generation}

Ethanol yield estimates from sugarcane is based on yield per ton of sugarcane. In addition, the production of bagasse from the cane stalk available for electricity generation were collected and analysed as per the following bagasse-steam-electrical power norms at Kakira sugar estate:

i. Bagasse production is $40 \%$ of sugarcane production

ii. Moisture $\%$ in bagasse is $50 \%$

iii. 1.0 ton of bagasse produces 2.0 tons of steam

iv. 5.0 tons of steam produces $1.0 \mathrm{Mwh}$ electrical power

Therefore 2.5 tons of bagasse produces 5.0 tons of steam which will generate $1.0 \mathrm{Mwh}$ electrical power. The electric power used in Kakira is hence generated from a renewable biomass energy source.

In 2005, Kakira had two 20 bar steam-driven turbo-generators ( $3 \mathrm{MW}+1.5 \mathrm{MW}$ ) in addition to 5 diesel standby generators. Thereafter, two new boilers of 50 tonnes per hour steam capacity at 45 bar-gauge pressure, with all necessary ancillaries such as an ash handing system, a feed water system and air pollution controls (such as wet scrubbers and a $40 \mathrm{~m} 30$ high chimney) were installed

\subsection{Contribution to household income and food security}

Indicative economic assessments included the use of gross sales for the raw material (farm gate) and ethanol. Annualized sugarcane net sales were compared to household annual expenditures to allow assessment of cane contribution to household income. Integration of commodity prices gives insight on the potential contribution of bio-fuels to household poverty alleviation and overall development of rural areas. 


\section{Results}

\subsection{Suitability}

The agro-ecological settings favor the growing of sugarcane with a potential 10,212,757 ha (49.6\%) at a marginal level of production with 2,558,698 ha (12.4\%) land area potentially not suitable for cane production. Although the current production is far below the potential production "in [12]", the related cane production is 908,935,330 and 60,769,069 tons respectively. It is also evident that there is possibility of increasing production through expansion of land area under sugarcane.

1. Suitability of sugarcane production and conflict visualization between food crops and gazetted areas in Uganda
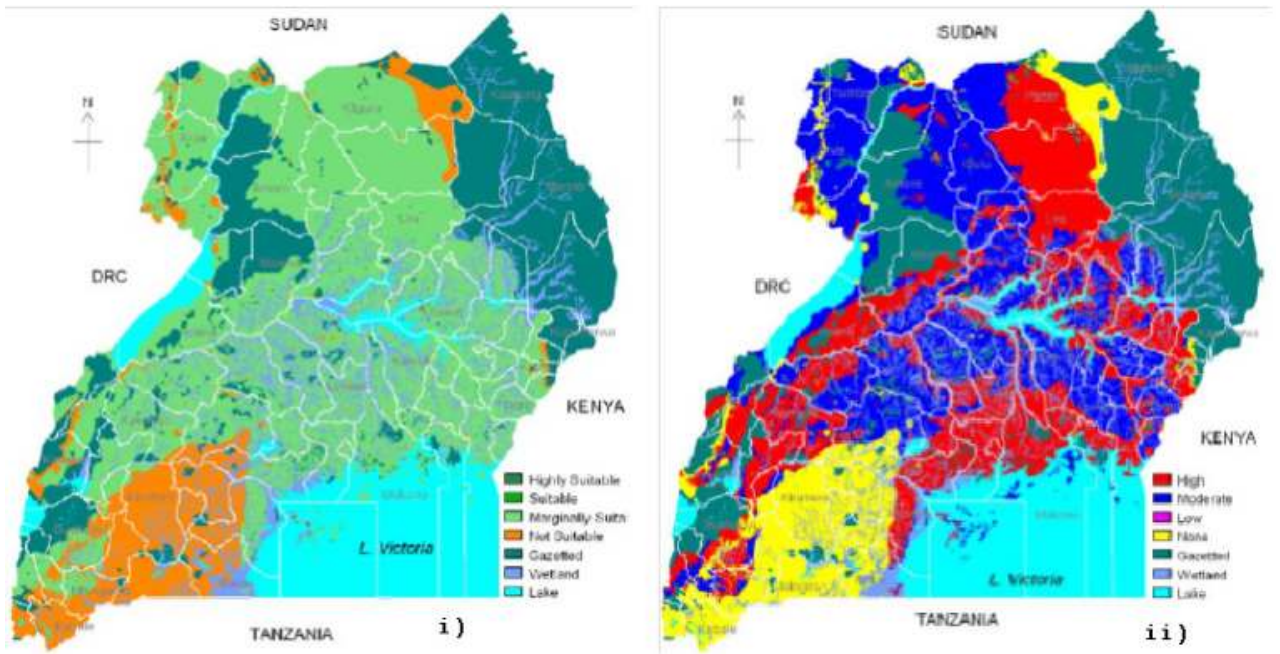

Figure 3. Sugar cane suitability ratings (i) and conflict visualization between food crops and gazetted areas

The marginal productivity of cane in Uganda is a function of Rainfall amount and the atmospheric temperature. Nevertheless the average optimum yields ( 89 ton / ha) at marginal level of productivity are comparable to yields of 85 ton / ha in a commercialized production in Brazil "in [13]".

Expanding acrage under sugarcane is likely to increase pressure on gazetted biodiversity rich areas including wetlands with consequent potential loss of bio-diversity.

Sugarcane and maize (food crop) have similar ecological requirements, presenting a situation of high potential land-use conflict as $49.6 \%$ of arable land can be grown with both sugarcane and food crops (figure 3 i). Figure 3 ii), shows $14 \%$ of the land where sugarcane has potential conflict with gazetted areas of which $4.3 \%$ has potential conflict with forest reserves. 
Sugarcane, given its energy balance advantage, is likely to be beneficial if promoted as biofuel feedstock as this is likely to increase sugarcane prices to the benefit of the small scale farmer.

\subsection{Agronomy}

The beneficial effects of integrated agronomic practices like reduced tillage operations, balanced fertilization; organic recycling of mill by-products (filter mud and boiler ash); intercropping with legumes; green manuring with sunn hemp; crop residue recycling through cane trash blanketing in ratoons by green cane harvesting to sustain soil fertility and cane productivity in monoculture sugarcane based cropping system are presented and discussed. Partitioning of dry matter between plant and ratoon crops of cane grown on the estate and Outgrowers fields were quantified and also presented in this chapter.

\subsubsection{Influence of agronomic practices on cane yield and cane productivity}

\subsubsection{Green manuring}

There was considerable increase in cane yield $(7.92 \mathrm{tc} / \mathrm{ha})$ and cane productivity $(0.62$ $\mathrm{tc} / \mathrm{ha} / \mathrm{m}$ ) in plant and ratoon crops due to green manuring as compared to blocks without green manuring (Table 1).

\begin{tabular}{|l|c|c|c|c|c|c|}
\hline \multirow{2}{*}{ Crop cycle } & \multicolumn{2}{|c|}{ Green manuring } & \multicolumn{2}{c|}{ No green manuring } & \multicolumn{2}{c|}{ Variance } \\
\cline { 2 - 7 } & $\begin{array}{c}\text { Yield } \\
\text { tc/ha }\end{array}$ & $\begin{array}{c}\text { Productivity } \\
\text { tc/ha/m }\end{array}$ & $\begin{array}{c}\text { Yield } \\
\text { tc/ha }\end{array}$ & $\begin{array}{c}\text { Productivity } \\
\text { tc/ha/m }\end{array}$ & $\begin{array}{c}\text { Yield } \\
\text { tc/ha }\end{array}$ & $\begin{array}{c}\text { Productivity } \\
\text { tc/ha/m }\end{array}$ \\
\hline Plant & 125.3 & 5.9 & 112.2 & 5.2 & 13.1 & 0.8 \\
\hline Ratoon 1 & 95.3 & 5.8 & 92.4 & 5.0 & 2.8 & 0.8 \\
\hline Ratoon 2 & 92.4 & 5.0 & 84.6 & 4.7 & 7.8 & 0.3 \\
\hline \# average & 104.3 & 5.6 & 96.4 & 5.0 & 7.9 & 0.6 \\
\hline
\end{tabular}

Table 1. Cane yield and cane productivity variance due to green manuring

Growing sunn hemp (Crotolaria juncia) during fallow period for in-situ cultivation has been a common practice to improve soil health on the estate since 2004 . Sunn hemp at $50 \%$ flowering on average produces $27.4 \mathrm{t} / \mathrm{ha}$ and $5.9 \mathrm{t} / \mathrm{ha}$ of fresh and dry weights respectively. It contains $2.5 \% \mathrm{~N}$ on oven dry basis and adds about $147 \mathrm{~kg} \mathrm{~N} / \mathrm{ha}$ to the soil. Of this amount, $30 \%$ (44kg N/ha) is presumed to be available to the succeeding sugarcane plant crop. "[11]" reported that $\mathrm{N}$ available to sugarcane ranges between $30-60 \%$ of total $\mathrm{N}$ added to soils in South Africa.

\subsubsection{Balanced fertilization}

The results indicated that application of $\mathrm{N}$ to plant crop at $100 \mathrm{~kg} / \mathrm{ha}$, phosphorus at $160 \mathrm{~kg}$ $\mathrm{P}_{2} \mathrm{O}_{5} / \mathrm{ha}$, potassium at $100 \mathrm{~K}_{2} \mathrm{O} / \mathrm{ha}$ and sulphur at $40 \mathrm{~kg} /$ ha significantly increased the cane yields by $23.3 \mathrm{tc} / \mathrm{ha} ; 22.25 \mathrm{tc} / \mathrm{ha} ; 12.07 \mathrm{tc} / \mathrm{ha}$ and $8.71 \mathrm{tc} /$ ha respectively over no application of 
N, P, K and S. Sugar yields were also improved due to N, P, K and S application by 2.91 ts/ha; 2.17 ts/ha; 2.88 ts/ha and 0.44 ts/ha respectively as compared to no application (Table 2 ).

\begin{tabular}{|c|c|c|}
\hline \multirow{2}{*}{ Nutrient levels (kg/ha) } & \multicolumn{2}{|c|}{ Attributes } \\
\cline { 2 - 3 } & Cane yield (tc/ha) & Sugar yield (ts/ha) \\
\hline N levels: 0 & 112.68 & 15.69 \\
\hline 50 & 124.38 & 17.08 \\
\hline 100 & 135.98 & 18.60 \\
$\mathrm{P}_{2} \mathrm{O}_{5}$ levels: 0 & 108.70 & 14.51 \\
\hline 80 & 120.40 & 16.34 \\
\hline 160 & 130.95 & 18.01 \\
\hline $\mathrm{K}_{2} \mathrm{O}$ levels: 0 & 108.06 & 15.58 \\
\hline 50 & 124.86 & 17.32 \\
\hline 100 & 134.13 & 18.46 \\
\hline Sulphur levels: 0 & 113.90 & 11.92 \\
\hline 40 & 122.61 & 12.36 \\
\hline $\mathrm{CD}$ at $5 \%: \mathrm{N}$ & 10.69 & 1.20 \\
\hline $\mathrm{P}_{2} \mathrm{O}_{5}$ & 9.80 & 1.18 \\
\hline $\mathrm{K}_{2} \mathrm{O}$ & 9.06 & 1.06 \\
\hline $\mathrm{S}$ & 6.94 & 0.32 \\
\hline
\end{tabular}

Table 2. Influence of N, P, K and S nutrition on cane and sugar yields

Balanced fertilizer application is very vital for crop growth. Adequate amounts of especially the major nutrients need to be supplied for proper crop growth. Excessive application of $\mathrm{N}$ in cane plant crop has been shown to inhibit the activity of free living $\mathrm{N}$-fixing bacteria and chloride ions from Muriate of potash adversely affecting soil microbial populations "in [14]".

\subsubsection{Mill by-products}

Millable stalk population at harvest was significantly higher due to application of filter mud and boiler ash $+100 \%$ recommended dose of fertilizers (RDF) than all other treatment combinations. However, there was no significant effect on stalk length, number of internodes and stalk weight due to different treatments. Cane and sugar yields were significantly higher by $30.2 \mathrm{tc} / \mathrm{ha}$ and $3.8 \mathrm{ts} / \mathrm{ha}$ respectively due to application of filter mud and boiler ash $+100 \%$ RDF. The data are presented in Table 3 .

Cane-mill by-products (filter mud and boiler ash) do contain valuable amounts of N, P, K, $\mathrm{Ca}$, and several micronutrients "in [15]". These in addition to the inorganic fertilizers applied considerably increased cane yields as compared to treatments which received only inorganic fertilizers. In [11] it is also showed that organic wastes-including filter mud and bolier ash could be used as an alternative source of nutrients in cane cultivation. 


\begin{tabular}{|ll|c|c|}
\hline \multicolumn{2}{|l|}{ Treatment } & \multicolumn{2}{|c|}{ Yield (T/ha) } \\
\cline { 3 - 4 } & Cane & Sugar (Estimated) \\
\hline $1 . \quad 100 \%$ recommended dose of fertilizers (RDF) & 131.6 & 16.6 \\
\hline 2. Filter mud + Boiler ash @ 32 + 8 T/ha alone & 122.1 & 16.2 \\
\hline 3. $\quad 100 \%$ RDF+ Filter mud + Boiler ash @ 32+8 T/ha & 161.7 & 20.4 \\
\hline $4 . \quad 75 \%$ RDF+ Filter mud + Boiler ash @ 32+8 T/ha & 143.8 & 17.5 \\
\hline $5 . \quad 50 \%$ RDF+ Filter mud + Boiler ash @ 32+8 T/ha & 142.1 & 17.3 \\
\hline $6 . \quad 25 \%$ RDF+ Filter mud + Boiler ash @ 32+8 T/ha & 135.0 & 16.6 \\
\hline CD @ 5\% & 12.3 & 1.9 \\
\hline
\end{tabular}

Table 3. Influence of mill by-products on cane and sugar yields

\subsubsection{Partitioning of bio-mass}

Among the crop cycles, plant crop recorded higher bio-mass production than succeeding ratoons. The production of crop residues were also higher $(50.7 \mathrm{t} / \mathrm{ha})$ in plant crop than $1^{\text {st }}$ ( $45.7 \mathrm{t} / \mathrm{ha}$ and $2^{\text {nd }}(36.6 \mathrm{t} / \mathrm{ha})$ ratoons. The data are presented in the Table 4 below.

\begin{tabular}{|l|c|c|c|c|c|c|}
\hline Crop cycle & $\begin{array}{c}\text { Cane weight } \\
(\mathrm{Tc} / \mathrm{ha})\end{array}$ & $\begin{array}{c}\text { Tops weight } \\
(\mathrm{T} / \mathrm{ha})\end{array}$ & $\begin{array}{c}\text { Trash } \\
\text { weight } \\
(\mathrm{T} / \mathrm{ha})\end{array}$ & $\begin{array}{c}\text { Total } \\
\text { bio- } \\
\text { mass } \\
(\mathrm{T} / \mathrm{ha})\end{array}$ & $\begin{array}{c}\text { Tops }+ \\
\text { Trash } \\
\text { weight } \\
\mathrm{T} / \mathrm{ha}\end{array}$ & $\begin{array}{c}\text { \% over } \\
\text { total }\end{array}$ \\
\hline Plant & 137.5 & 30.3 & 20.4 & 188.2 & 50.7 & 27.0 \\
\hline Ratoon 1 & 124.9 & 26.8 & 18.9 & 170.59 & 45.7 & 27.0 \\
\hline Ratoon 2 & 107.5 & 19.7 & 16.8 & 144.02 & 36.6 & 25.4 \\
\hline \# average & 123.3 & $\begin{array}{c}\text { Fresh: } 25.6 \\
\text { Dry: } 9.0\end{array}$ & $\begin{array}{c}\text { Fresh: } 18.7 \\
\text { Dry: } 16.9\end{array}$ & - & $\begin{array}{c}\text { Fresh: } 44.3 \\
\text { Dry: 25.8 }\end{array}$ & 26.4 \\
\hline
\end{tabular}

Table 4. Crop-wise partitioning of bio-mass

Results indicate that on average, 25.8 tons of dry matter (cane trash and tops) is produced from each crop cycle at harvest. In burnt cane harvesting system, all this dry matter is lost unlike in green cane harvesting. This explains the gradual decline in cane yield in such harvesting systems. The decline is presumed to be due to deteriorating organic matter and other physical and chemical properties of the soil "in [11]".

After decomposition of cane trash, $139 \mathrm{~kg} \mathrm{~N}, 59 \mathrm{~kg} \mathrm{P}_{2} \mathrm{O}_{5}, 745 \mathrm{~kg} \mathrm{~K} 2 \mathrm{O}, 41 \mathrm{~kg} \mathrm{Ca}, 46 \mathrm{~kg} \mathrm{Mg}$ and $34 \mathrm{~kg} \mathrm{~S} / \mathrm{ha}$ were added to the soils and these added nutrients would be available to the succeeding crop at $30 \%$ of the total nutrients " in [11] ". The nutrient concentration of crop residues (trash + tops) were taken into account for computing nutrient additions to the soil and their availability to the succeeding ratoon crops and the data are presented in Table 5 . 


\begin{tabular}{|l|c|c|c|}
\hline Nutrient status of crop residues (\%) & $\begin{array}{c}\text { Total dry matter } \\
(\mathrm{T} / \mathrm{ha})\end{array}$ & \multicolumn{2}{|c|}{ Total nutrients } \\
\cline { 3 - 5 } & & $\begin{array}{c}\text { Added } \\
\text { to soil } \\
(\mathrm{kg} / \mathrm{ha})\end{array}$ & $\begin{array}{c}\text { Available to crops @ 30\% } \\
(\mathrm{kg} / \mathrm{ha})\end{array}$ \\
\hline $\mathrm{N}: 0.54$ & 25.8 & 139 & 42 \\
\hline $\mathrm{P}_{2} \mathrm{O}_{5}: 0.23$ & 25.8 & 59 & 18 \\
\hline $\mathrm{K} \mathrm{K}_{2}: 2.89$ & 25.8 & 745 & 223 \\
\hline $\mathrm{Ca}: 0.16$ & 25.8 & 41 & 12 \\
\hline $\mathrm{Mg}: 0.18$ & 25.8 & 46 & 14 \\
\hline $\mathrm{S}: 0.13$ & 25.8 & 34 & 10 \\
\hline
\end{tabular}

** Adopted from [11]

Table 5. Nutrient status of crop residues and their availability to the succeeding crops

\subsection{Renewable energy potential}

\subsubsection{Ethanol productivity}

Sugarcane, given its energy balance advantage, is likely to be beneficial if promoted as bio-fuel feedstock as this is likely to increase sugarcane prices to the benefit of the small scale farmer.

Promoting sugarcane as a feedstock for ethanol is likely to improve rural livelihood and also minimize on forest encroachment since energy output per unit land area is very high for sugarcane.

In Brazil for example the production of sugar cane for ethanol only uses $1 \%$ of the available land and the recent increase in sugar cane production for bio-fuels is not large enough to explain the displacement of small farmers or soy production into deforested zones "in [13]".

To minimize competition over land, it is advisable to grow sugarcane that has high yields with higher energy output compared to other biofuel crops. High yielding bio-fuels are preferable as they are less likely to compete over land "in [16]".

\subsubsection{Bioelectricity generation}

Hydropower contributes about 90 per cent of electricity generated in Uganda with sugarcane based bagasse bioelectricity, fossil fuel and solar energy among other sources of power. Although the current generation of $800 \mathrm{MW}$ "in [18] ". has boosted industrial growth, the capacity is still lagging behind the demand that is driven by the robust growth of the economy.

The low pressure boilers of 45 bar currently generate $22 \mathrm{MW}$ of which $10 \mathrm{MW}$ is connected to the grid. However, Kakira sugar estate has a target of generating $50 \mathrm{MW}$ of electricity with the installation of higher pressure boilers of 68 bar in 2013. This target can be surpassed given the abundance of the bagasse (Table 6 and 7). 


\begin{tabular}{lccccc}
\hline Particulars & Plant & Ratoon 1 & Ratoon 2 & Ratoon 3 & $\begin{array}{c}\text { Total/ } \\
\text { average }\end{array}$ \\
\hline Cane harvest area (ha) & $1,461.1$ & $1,541.7$ & $1,535.2$ & 392.8 & $4,930.8$ \\
Total cane supply (tons) & $155,207.3$ & $162,132.3$ & $137,436.4$ & $40,138.9$ & $494,915.9$ \\
Average cane yield (tc/ha) & 106.23 & 105.16 & 89.52 & 87.28 & 100.37 \\
Average harvest age (months) & 19.20 & 18.15 & 17.98 & 16.50 & 17.96 \\
Cane productivity (tc/ha/m) & 5.53 & 5.79 & 4.97 & 5.29 & 5.40 \\
Bagasse production /ha & 42.49 & 42.06 & 35.80 & 34.90 & 40.14 \\
Steam generation (tons /ha) & 84.98 & 84.12 & 71.60 & 69.80 & 80.28 \\
Electric power generation & 17.00 & 16.82 & 14.32 & 13.96 & 16.05 \\
(Mwh/ha) & & & & & \\
\hline
\end{tabular}

*This electric power generation is calculated based on using low pressure boilers of 45 bar at Kakira estate

Table 6. Mean estate cane production/productivity, electrical generation* norms $(2008-2012)$

\begin{tabular}{|c|c|c|c|c|c|}
\hline Particulars & Plant & Ratoon 1 & Ratoon 2 & Ratoon 3 & $\begin{array}{c}\text { Total/ } \\
\text { average }\end{array}$ \\
\hline Cane harvest area (ha) & $3,429.3$ & $3,206.9$ & $2,334.7$ & $1,431.3$ & $10,402.2$ \\
\hline $\begin{array}{l}\text { Total cane supply } \\
\text { (tons) }\end{array}$ & $320,100.20$ & $290,073.29$ & $188,274.65$ & $113,837.25$ & $912,285.49$ \\
\hline $\begin{array}{l}\text { Average cane yield } \\
\text { (tc/ha) }\end{array}$ & 93.34 & 90.45 & 80.64 & 79.53 & 87.70 \\
\hline $\begin{array}{l}\text { Average harvest age } \\
\text { (months) }\end{array}$ & 18.50 & 17.50 & 18.00 & 16.00 & 17.50 \\
\hline $\begin{array}{l}\text { Cane productivity } \\
(\mathrm{tc} / \mathrm{ha} / \mathrm{m})\end{array}$ & 5.05 & 5.17 & 4.48 & 4.97 & 5.01 \\
\hline Bagasse production /ha & 37.30 & 36.18 & 32.25 & 31.81 & 35.08 \\
\hline $\begin{array}{l}\text { Steam generation (tons } \\
\text { /ha) }\end{array}$ & 74.60 & 72.36 & 64.50 & 63.62 & 70.16 \\
\hline $\begin{array}{l}\text { Electric power } \\
\text { generation (Mwh/ha) }\end{array}$ & 14.90 & 14.50 & 12.90 . & 12.70 & 14.00 \\
\hline
\end{tabular}

*This electric power generation is calculated based on using low pressure boilers of 45 bar at Kakira estate Tc $=$ Tons of cane

Table 7. Mean outgrowers cane production/productivity, electrical generation* norms (mean for 2008 2012)

Putting into consideration the productivity norms at Kakira estate and outgrowers (Table 8), with a potential of producing $908.9 \mathrm{~m}$ tons of sugarcane, Uganda has a potential of producing bio-electricity that surpasses the nation's demand by far. Much of this electrical power can be exported to the region, greatly expanding on Uganda's export base. 


\begin{tabular}{|c|c|c|c|c|c|}
\hline Particulars & Plant & Ratoon 1 & Ratoon 2 & Ratoon 3 & $\begin{array}{c}\text { Total/ } \\
\text { average }\end{array}$ \\
\hline Cane harvest area (ha) & $4,890.4$ & $4,748.6$ & $3,869.9$ & $1,824.1$ & $15,333.0$ \\
\hline $\begin{array}{l}\text { Total cane supply } \\
\text { (tons) }\end{array}$ & $475,307.50$ & $452,205.60$ & $325,711.05$ & $153,976.15$ & $1,407,200.4$ \\
\hline $\begin{array}{l}\text { Average cane yield } \\
\text { (tc/ha) }\end{array}$ & 97.19 & 95.22 & 84.17 & 84.41 & 91.78 \\
\hline $\begin{array}{l}\text { Average harvest age } \\
\text { (months) }\end{array}$ & 18.75 & 17.75 & 18.00 & 16.00 & 17.65 \\
\hline $\begin{array}{l}\text { Cane productivity } \\
(\mathrm{tc} / \mathrm{ha} / \mathrm{m})\end{array}$ & 5.18 & 5.36 & 4.67 & 5.27 & 5.20 \\
\hline $\begin{array}{l}\text { Bagasse production } \\
\text { /ha }\end{array}$ & 38.88 & 38.09 & 33.67 & 33.76 & 36.71 \\
\hline $\begin{array}{l}\text { Steam generation (tons } \\
\text { /ha) }\end{array}$ & 77.76 & 76.18 & 67.34 & 67.52 & 73.42 \\
\hline $\begin{array}{l}\text { Electric power } \\
\text { generation (Mwh/ha) }\end{array}$ & 15.55 & 15.24 & 13.47 & 13.50 & 14.68 \\
\hline
\end{tabular}

Table 8. Combined (Estate + Outgrowers cane production/productivity, Electrical power generation* norms (mean for 2008 - 2012)

\subsection{Household income and food security}

The competition for resources between sugarcane and food crops is apparent with foreseen consequent increased food insecurity. Fifty percent of the arable land area good for food crop production is equally good for sugarcane.

A farm household that allocates all of its one hectare of land to sugarcane is expected to earn 359 \$ at high input level, 338 \$ at intermediate level and 261 \$ at low input level " in [4] ". The $391 \$$ required to purchase maize meal is well above the net margins from one ha. This shows that proceeds from one hectare cannot sustain a household of 5 . It is further revealed that maize produced from 0.63 ha can sustain a household nutritionally; however considering the annual household expenditure (760.8 \$; "in [17] "), about three hectares of land under sugarcane are required at low input level to support a household " in $[4]^{\prime \prime}$.

However, this study reveals that sugarcane sales accrued from ethanol under a scenario of a flourishing bio-fuel industry is associated with increased income that is likely to support households (Table 9). An ethanol gross sale per person per day is 1.6 dollars; an indication that the cultivation of sugarcane based biofuel is likely to contribute to alleviation of household poverty. A trickle-down effect on household income is expected from a foreseen expansion of bagasse-based electricity generation beyond the estate into the national electricity grid. 


\begin{tabular}{|c|c|c|c|c|c|c|c|}
\hline \multicolumn{2}{|c|}{ Production / year } & \multicolumn{3}{c|}{ Gross sales } & \multicolumn{3}{c|}{ Conflict } \\
\hline $\begin{array}{c}\text { Cane } \\
\text { production }\end{array}$ & Billion & Farm & Ethanol & Capita & Food & Gazetted & Forest \\
\hline ton & litres & \multicolumn{5}{|c|}{ /ha/year } & \multicolumn{3}{c|}{$\%$} \\
\hline $908.9 \mathrm{~m}$ & 75.4 & 1869 & 22161 & 1.6 & 50.0 & 14.0 & 4.3 \\
\hline \multicolumn{6}{|l|}{ Sugarcane= USD 21/ton: projected population of 33 $\mathrm{m}$ in 2009 is used } \\
\hline
\end{tabular}

Table 9. Sugarcane productivity, sales and potential land-use conflict

\section{Further research}

The expansion of cane production is largely driven by market forces oblivious to the detrimental impact the industry is likely to have on food, livelihood security and the status of biodiversity. In addition to lack of appropriate policies to support the small-scale cane farmer, the policies are largely sectoral with no linkages with other relevant policies. Information is required to support the sustainable development of the cane industry with minimal negative impact on food and livelihood security and the status of biodiversity.

\section{Relevant questions to explore among others include}

Can food crop productivity be improved in the context of a sugarcane-based farming system?

Can the understanding of the dimensions of food and livelihood security in sugarcanebased farming systems inform the synergistic development and review of relevant policies in the food, agriculture, health, energy, trade and environment sectors? What are the social impacts of the industry in light of the various agro-ecological zones of the country? What is the gender based livelihood strategies with special emphasis on labor exploitations- child labor etc?

What do people consider as possible options for improving food and livelihood security in a sugarcane-based farming system? Do these options differ between different actors (local women and men, NGOs and government)? How do families cope with food inadequacy, inaccessibility and malnutrition?

Can the study inform the carbon credit market initiative for farming systems in Uganda through the climate smart agriculture concept? Are the proposed assessment tools appropriate for Ugandan situations and the cane-based systems in particular?

\section{Conclusion}

Driven by the need to meet the increasing local and regional sugar demand, and fossil fuel import substitution, cane expansion has potential negative impact on food security and biodiversity. However, this negative impact parallels the benefits related to cane cultivation. Cane biomass yield can be improved and sustained through the integrated use of various 
practices reported in this study. Consequently this reduces the need to expand land acreage under cane while releasing land for use in food crop productivity. The high biomass returned to the ground sequesters carbon thereby offering the opportunity for sugarcane based farmers to earn extra income through the sale of carbon credits. Trickle down effects are expected to increase household income through the production and marketing of cane based biofuel and electricity.

These developments are expected to improve the farmers purchasing power, making households to be less dependent on the land and more food secure financially.

\section{Author details}

Moses Isabirye*

Faculty of Natural Resources and Environment, Namasagali Campus, Busitema University, Kamuli, Uganda

D.V.N Raju

Research and Dev't Section - Agricultural Department Kakira Sugar Limited, Jinja, Uganda

M. Kitutu

National Environment Management Authority, Kampala, Uganda

V. Yemeline

UNEP/GRID-Arendal, Norway

J. Deckers and J. Poesen

Katholieke Universiteit Leuven, Department of Earth and Environmental Sciences, Celestijnenlaan Leuven, Belgium

\section{Acknowledgement}

Financial support for the various studies reported in this chapter was provided by UNEP GRID-Arendal, Kakira Sugar Limited and Belgian Technical Cooperation (BTC). The National Environment Management Authority and the National Agricultural Research Organization in Uganda gave the facilities and technical support that enabled the accomplishment of studies reported here.

\section{References}

[1] Bahiigwa B. A. Godfrey, 1999 Household Food Security In Uganda: An Empirical Analysis, Economic Policy Research Center, Kampala, Uganda

[2] Uganda government, 2002b Uganda Food and Nutrition Policy, Ministry of Agriculture, Animal Industry and Fisheries, Ministry of Health, Kampala, Uganda

\footnotetext{
${ }^{*}$ Corresponding Author
} 
[3] USCTA (2001) The Uganda Sugarcane Technologist's Association, Fourth Annual Report, 2001, Kakira, Uganda.

[4] Isabirye (2005) Land Evaluation around Lake Victoria: Environmental Implications for Land use Change, PhD Dissertation, Katholieke Universiteit, Leuven, Belgium

[5] MEMD (2007) The Renewable Energy Policy for Uganda. MEMD, Kampala, Uganda.

[6] MEMD (2010) The Uganda Energy Balance Report., MEMD, Kampala, Uganda.

[7] Bio-fuel-news (2009) Uganda to produce cellulosic ethanol in a year. Bio-fuel International volume 3, issue 10,2009, http://www.Bio-fuel-news.com/magazine_store.php?issue_id=34

[8] Meteorology Department (1961) Climate data, Meteorological Department, Entebbe Uganda

[9] Chenery (1960) Introduction to the soils of the Uganda Protectorate, Memoirs of the Research Division, Series 1- Soils, Number 1, Department of Agriculture, Kawanda Research Station, Uganda

[10] FAO (1983) Guidelines: Land evaluation for rainfed agriculture. FAO Soils Bulletin 52, Food and Agricultural Organization of the United Nations, Rome

[11] Antwerpen R. V. (2008) Organic wastes as an alternative source of nutrients. The link published by SASRI. Vol. 17 No. 2: May 2008. 8-9.

[12] FAOStat (2012) http://faostat.fao.org/site/339/default.aspx Sunday, May 06, 2012

[13] Xavier M.R. (2007) The Brazilian sugarcane ethanol experience. Issue Analysis, no. 3, Washington, USA, Competitive Enterprise Institute. $11 \mathrm{p}$.

[14] Carr Carr, A.P, Carr, D.R, Carr, I.E, Wood, A.W and Poggio, M. (2008) Implementing sustainable farming practices in the Herbert: The Oakleigh farming company experience

[15] Raju, D.V.N and Raju, K.G.K (2005) Sustainable sugarcane production through integrated nutrient management. In: Uganda Sugarcane Technologists' Association $17^{\mathrm{TH}}$ Annual Technical Conference.

[16] Pesket Leo, Rachel Slater, Chris Steven, and Annie Dufey (2007) Biofuels, Agriculture and Poverty Reduction. Natural Resource Perspectives 107, Overseas Development Institute, 111 Westminster Bridge Road, London SE1 7JD

[17] UBOS (2001) Uganda National household survey 1999/2000; Report on the socioeconomic. Uganda Bureau of Statistics, Entebbe, Uganda. www.ubos.org

[18] Ibrahim Kasita (2012) Strategic plan to increase power supply pays dividends, New Vision, Publish Date: Oct 09, 2012 